1. MS (Urology) Associate Professor Urology Sahara Medical College, Narowal.

2. MS (Urology)

Associate Professor Urology CMH Medical College Lahore.

3. MS (Urology)

Senior Registrar Urology

University College of Medicine and Dentistry, Lahore.

4. MS (Urology)

Assistant Professor Urology

Fatima Jinnah Medical University, Lahore.

5. MS (Urology)

Senior Registrar Urology Sahara Medical College, Narowal.

6. Ph.D, (Nephrology)

Assistant Professor Nephrology UCMD, Lahore.

Correspondence Address:

Dr. Sohail Hassan

Department of Urology

Sahara Medical College, Narowal.

drhassan_99@hotmail.com

Article received on:

15/07/2020

Accepted for publication:

27/01/2021

\section{Life style changes in above 50 years old patients presenting in Urology Department during COVID 19 pandemic - a multicenter survey.}

Sohail Hassan', M. Adil Khurshid², Muhammad lqbal ${ }^{3}$, Athar Hameed Sheikh ${ }^{4}$, Ammad Ahmad Siddiqui ${ }^{5}$, Manzoor Ahmad Naeem ${ }^{6}$

\begin{abstract}
Objective: In the current pandemic of COVID-19 the health care workers are working with social scientist to assist the government policy makers to slow the spread of this disease. These studies are focusing on different social aspects of the disease. Study Design: Cross Sectional Survey. Setting: Urology Outpatients Department of Four Hospitals. Period: May 2020. Material \& Methods: YouGov behavior change Performa was used for the survey with a 4 points scale from "Not at all" to "Drastic Change". Results: Total 285 patients were included in this study. Among these 191 patients were male while 94 were female. The age range was 50-68 years. Among 285 patients 159 an education level above primary. Among these 285 patients 234 patients $(82.1 \%)$ belong to urban area while 51 patients $(17.9 \%)$ belongs to rural area. Regarding change in behavior, 168 patients responded that there is no change, 56 showed a little change, 32 showed significant change and 28 showed drastic change in the habit of hand washing. In change in travel habit 128 mentioned not at all, 84 said a little change, 53 showed significant change and 20 said drastic change. In work from home 120 mentioned not at all, 88 said a little change, 57 showed significant change and 20 said drastic change. In piling of food and medicine 164 mentioned not at all, 96 said a little change and 25 showed significant change while there was no drastic change. In elderly and child care160 mentioned not at all, 68 said a little change and 57 showed significant change while there was no drastic change. In social distancing 160 mentioned not at all, 72 said a little change, 24 showed significant change and 29 said drastic change. In use of face mask 124 mentioned not at all, 132 said a little change, 24 showed significant change and 05 said drastic change. Conclusion: As there is no vaccine for this disease and treatment plans are also under trial so the role of preventive measures increases. The most important preventive measures are wearing of face masks, social distancing and avoidance of unnecessary traveling. As, at present, we can only decrease the spread of disease by adopting preventive measures.
\end{abstract}

Key words: Behavioural Response, COVID-19, Epidemic, Novel Coronavirus, YouGov.

Article Citation: Hassan S, Khurshid MA, lqbal M, Sheikh AH, Siddiqui AA, Naeem MA. Life style changes in above 50 years old patients presenting in Urology Department during COVID 19 pandemic - a multicenter survey. Professional Med J 2021; 28(10):1367-1371. https://doi.org/10.29309/TPMJ/2021.28.10.5625

\section{INTRODUCTION}

At the end of 2019, there was an outbreak of acute respiratory distress in the city of Wuhan China. The organism identified was a novel Corona Virus which is now designated as SARS-COV-2. The World Health Organization (WHO) named the disease as COVID-19 in February 2020. Clinically the patients suffering from COVID-19 infection presents with a range of asymptomatic to acute respiratory distress, septic shock and multi organ failure. ${ }^{1}$ The $\mathrm{WHO}$ declared the outbreak of COVID-19 as a public health emergency in all countries on 30th January 2020. In March 2020 it was declared as Pandemic and urged all countries to take all necessary actions for the early detection of infection and preventive measures to control its spread. ${ }^{2}$

It is thought the mode of spread of COVID-19 virus is through respiratory droplets mainly it spreads from person to person when the patient coughs or sneezes. There are other routes of spreads also such as inhalation of aerosols and contaminated fomites. The virus also spreads 
from asymptomatic patient and the patients within incubation period. ${ }^{1}$

Unfortunately, up till now, there is no specific medication approved by FDA for the management of COVID-19 infection. Although there are different drug trials are going on worldwide with a little or limited success. The most effective measure that a country take against this virus which is not only effecting the health of people but also the social norms and economy of the countries is the prevention of its spread. The $\mathrm{WHO}$ had published its interim guidelines on 7th March 2020 "Responding to Community Spread of COVID-19". These guidelines states that prevention of spread of COVID-19 is through the development of a mechanism of coordination not only in health sectors but also in other areas such as travelling, Financial institutes, security and other sectors of community. ${ }^{3}$

The virus of COVID-19 had an extraordinary property of spread as a result it is causing increased morbidity and mortality. ${ }^{4}$ Governments of all around the world had planned policies such as social distancing, wearing of face masks, limited movement, self-quarantine and isolation. ${ }^{5}$ In this COVID-19 pandemic the psychosocial and economical problems are increased all over. Millions of people are advised to remain in their homes (lock down) and most of them are not able to earn money because they cannot do their job from home. As a result they are worried about the continuity of their jobs.

The lead stories of all types of media is focusing on the number of infected individuals and deaths due to COVID-19. As a result there is a psychological effect on all individuals of the world. A recent study from Canada states that among 1354 adults, one third were worried about this virus of COVID-19. ${ }^{6}$ Similarly another study from Germany also reported that participants $(\mathrm{N}=1242)$ were also worried about COVID-19. ${ }^{7}$ In United States of America, on an online survey of 808 adults $56 \%$ showed their concern about COVID-19. ${ }^{7}$ In another study the participants reported that they are more worried about COVID-19 as compare to Influenza (37\% Vs 27\%). ${ }^{7}$
Communicating a moral advise in a proper way invoke a civic sense of duty among the individuals and as a result they change their behaviors to enhance a delay in the spread of virus. Due to this civic sense of duty a person feels interpersonal empathy. ${ }^{8}$ It is shown that American adolescents who showed higher levels of self interest were more likely to change their behavior and follow the recommendations of government. ${ }^{8}$ Trait empathy among the people encourages them to reduce the physical social interactions and maintain their behavior. $^{8}$

At this time when in Pakistan the disease COVID19 is spreading the researches are carried out on different aspects of this disease from prevention to treatment and on social aspects of this disease. In our study we tried to evaluate how many people who are not known case of COVID-19 had changed their behavior and if changed then how much in response to constant advise by the government and healthcare professionals. According to our knowledge there is no study conducted on this behavior change in patients of Pakistan. This research will not only add basic information about the behavior change but also invite more researchers to work on this aspect in more depth.

\section{MATERIAL \& METHODS}

This survey was conducted at four different hospitals among the patients, who were above 50 years of age, attending Urology OPD in the month of May 2020. These four centers were Sughra Shafi Medical Complex Narowal, Combined Military Hospital (CMH) Lahore, Sir Ganga Ram Hospital Lahore and Social Security Teaching Hospital Lahore. YouGov behavior change Performa was used for the survey which is being used in United States to assess the behavior changes with a 4 points scale from "Not at all" to "Drastic Change". ${ }^{9}$ An addition of "Use of Face Mask" was done in the Performa. This Performa was filled by taking an informed consent from the patients. All the data collected was entered in SPSS version 23 and frequencies were calculated.

\section{RESULTS}

Total 285 patients were included in this study. 
Among these 191 patients were male while 94 were female. In Sughra Shafi Medical Complex Narowal 46 patients, in Combined Military Hospital Lahore 70 patients, in Sir Ganga Ram Hospital 104 patients and in Social Security Teaching Hospital 65 patients reported and included in the study. The age range was $50-68$ years, male with a range of 50-68 and female with 50-62 years. Among 191 male patients 120 (63\%) have an education level above primary while among 94 female patients 39 (42\%) have an education level above primary level. Among these 285 patients 234 patients $(82.1 \%)$ belong to urban area while 51 patients (17.9\%) belongs to rural area.

The results of Yougov behavior changes are shown in the Table-I.

\section{DISCUSSION}

In this study we tried to explore multiple aspects of behavior changes in population due to COVID-19. Participants of this study reported their perception of behavior changes on a 4 point scale. In our study we found that there is mild to moderate level of changes in the behavior of people as most changes are at the level of 1 and 2 and there is a little change at the level of 4. The participants adopted the behavior change of washing their hands and social distancing the most. Other studies conducted on behavior changes also showed the same results but the changes in the behavior of their population were moderate to high that is level 3 and 4 are more than level 1 and 2.9.10,11,12 This may be due to a proper way of messaging by the governments, better understanding and a positive response of the people of these populations.

In our study the poorest response was on behavior change of piling of food and medicine and care elderly and child care. As most of the population reporting in our study belongs to a poor socioeconomical group so it was not possible for them to pile food or medicine so it reflected in their response to question. Mostly our population live in a joint family system and in this system the attitude of people is caring.

\begin{tabular}{|c|c|c|c|c|}
\hline Life Style & Not at all (1) & A Little (2) & $\begin{array}{l}\text { Significant } \\
\text { Change (3) }\end{array}$ & Drastic Change (4) \\
\hline Hand Washing & $\begin{array}{c}\mathrm{N}=168(58.9 \%) \\
\text { Male }=114(59.2 \%) \\
\text { Female }=54(57.4 \%)\end{array}$ & $\begin{array}{c}\mathrm{N}=56(19.6) \\
\text { Male }=37(19.4 \%) \\
\text { Female=19 }(20.2 \%)\end{array}$ & $\begin{array}{c}\mathrm{N}=32(11.2 \%) \\
\text { Male }=22(11.5 \%) \\
\text { Female }=10(10.6 \%)\end{array}$ & $\begin{array}{c}\mathrm{N}=28(10.2 \%) \\
\text { Male }=18(9.4 \%) \\
\text { Female }=11(11.7 \%)\end{array}$ \\
\hline Changed Travel & $\begin{array}{c}\mathrm{N}=128(44.9 \%) \\
\text { Male }=85(44.5 \%) \\
\text { Female }=43(45.7 \%\end{array}$ & $\begin{array}{c}\mathrm{N}=84(29.5 \%) \\
\text { Male }=56(29.3 \%) \\
\text { Female }=28(29.8 \%)\end{array}$ & $\begin{array}{c}\mathrm{N}=53(18.6 \%) \\
\text { Male }=35(18.3 \%) \\
\text { Female=18 }(19.1 \%)\end{array}$ & $\begin{array}{c}\mathrm{N}=20(07 \%) \\
\text { Male }=15(7.8 \%) \\
\text { Female }=05(5.3 \%)\end{array}$ \\
\hline Work from Home & $\begin{array}{c}\mathrm{N}=120(42.1 \%) \\
\text { Male }=85(44.5 \%) \\
\text { Female=35 (37.2\%) }\end{array}$ & $\begin{array}{c}\mathrm{N}=88(30.9 \%) \\
\text { Male }=60(31.4 \%) \\
\text { Female }=28(29.8 \%)\end{array}$ & $\begin{array}{c}\mathrm{N}=57(20 \%) \\
\text { Male }=32(16.7 \%) \\
\text { Female }=25(26.6 \%)\end{array}$ & $\begin{array}{c}\mathrm{N}=20(07 \%) \\
\text { Male }=14(7.3 \%) \\
\text { Female }=6(6.4 \%)\end{array}$ \\
\hline $\begin{array}{l}\text { Food and Medicine } \\
\text { Piling }\end{array}$ & $\begin{array}{c}\mathrm{N}=164(57.4 \%) \\
\text { Male=110 (57.6\%) } \\
\text { Female=54 (57.4\%) }\end{array}$ & $\begin{array}{c}\mathrm{N}=96(33.7 \%) \\
\text { Male }=64(38.5 \%) \\
\text { Female }=32(34 \%)\end{array}$ & $\begin{array}{c}\mathrm{N}=25(8.6 \%) \\
\text { Male }=17(8.9 \%) \\
\text { Female }=08(8.5 \%)\end{array}$ & \\
\hline Social Distancing & $\begin{array}{c}\mathrm{N}=160(56.1 \%) \\
\text { Male=101 }(52.9 \%) \\
\text { Female=59 (62.8\%) }\end{array}$ & $\begin{array}{c}\mathrm{N}=72(25.4 \%) \\
\text { Male }=51(26.7 \%) \\
\text { Female=21 }(22.3 \%)\end{array}$ & $\begin{array}{c}\mathrm{N}=24(8.4 \%) \\
\text { Male }=13(6.8 \%) \\
\text { Female }=11(11.7 \%)\end{array}$ & $\begin{array}{c}\mathrm{N}=29(10.1 \%) \\
\text { Male }=26(13.6 \% \\
\text { Female }=03(3.1 \%)\end{array}$ \\
\hline Use of Mask & $\begin{array}{c}\mathrm{N}=124(43.5 \%) \\
\text { Male }=86(45 \%) \\
\text { Female=38 }(40.4 \%)\end{array}$ & $\begin{array}{c}\mathrm{N}=132(46.3 \%) \\
\text { Male }=88(46 \%) \\
\text { Female }=44(46.8 \%)\end{array}$ & $\begin{array}{c}\mathrm{N}=24(8.4 \%) \\
\text { Male }=15(7.8 \%) \\
\text { Female }=09(9.6 \%)\end{array}$ & $\begin{array}{c}\mathrm{N}=05(1.7 \%) \\
\text { Male }=02(1 \%) \\
\text { Female }=03(3.2 \%)\end{array}$ \\
\hline
\end{tabular}


So they already caring their elderly and children so no extra effort is required to change their behavior. As the population belongs to poor socio-economical class and literacy rate is not too high so there is, also, a poor response for "working from home". Most of small organizations have no IT department to support this and the people have less number of personal computers and access to internet. There is no satisfactory (change at level 3 and 4) change in behavior of wearing face masks despite the fact the population reporting in this study were hospital visitors where wearing of mask is necessary which reflects a poor messaging technique and response of the population. In this study there is no significant difference in the behavior change among male and female population.

Our study is a small representative of community showing behavior changes at initial level. This study can help the stakeholders to work on those areas which are important but people are responding less such as wearing of face masks. The population included are poor economically and have less literacy rate with a poor response to behavior change in this COVID-19 pandemic. It suggests that unless the government does not intervene to educate and support the people, there will be a bad impact of this epidemic on the society. A change in behavior is also observed in previous pandemics which showed a wide variety of responses against different preventive measures. ${ }^{13,14,15}$

This study was conducted in a selected population (patients coming to hospitals). Moreover the number of participants are also small. The responses of behavior changes may vary between patients and normal population and on a larger scale.

\section{CONCLUSION}

As there is no vaccine for this disease and treatment plans are also under trial so the role of preventive measures increases. The most important preventive measures are wearing of face masks, social distancing and avoidance of unnecessary traveling. As, at present, we can only decrease the spread of disease by adopting preventive measures.

Copyright $@ 27$ Jan, 2021.

\section{REFERENCES}

1. Guan WJ, Ni ZY, Hu Y, Liang WH, Ou CQ, He JX, Liu L, Shan H, Lei CL, Hui DS, Du B. Clinical characteristics of coronavirus disease 2019 in China. New England journal of medicine. 2020 Apr 30; 382(18):1708-20.

2. GÜNER HR, HASANOĞLU i, AKTAŞ F. COVID-19: Prevention and control measures in community. Turkish Journal of medical sciences. 2020 Apr 21; 50(SI1):571-7.

3. World Health Organization. Responding to community spread of COVID-19: Interim guidance, 7 March 2020. World Health Organization; 2020

4. Lipsitch M, Swerdlow DL, Finelli L. Defining the epidemiology of Covid-19-studies needed. New England journal of medicine. 2020 Mar 26; 382(13):11946.

5. Anderson RM, Heesterbeek $H$, Klinkenberg D, Hollingsworth TD. How will country-based mitigation measures influence the course of the COVID-19 epidemic?. The Lancet. 2020 Mar 21; 395(10228):9314.

6. Asmundson GJ, Taylor S. Coronaphobia: Fear and the 2019-nCoV outbreak. Journal of anxiety disorders. 2020 Mar; 70:102196.

7. Pakpour AH, Griffiths MD. The fear of COVID-19 and its role in preventive behaviors. Journal of Concurrent Disorders. 2020; 2(1):58-63.

8. Harper CA, Satchell LP, Fido D, Latzman RD. Functional fear predicts public health compliance in the COVID-19 pandemic. International journal of mental health and addiction. 2020 Apr 27:1-4.

9. Atchison CJ, Bowman L, Vrinten C, Redd R, Pristera $\mathrm{P}$, Eaton JW, Ward H. Perceptions and behavioural responses of the general public during the COVID-19 pandemic: A cross-sectional survey of UK Adults. medRxiv. 2020 Jan 1.

10. Russell P. New coronavirus: UK public health campaign launched. Medscape. Archived from the original on. 2020 Mar; 1.

11. Bults M, Beaujean DJ, Richardus JH, Voeten HA. Perceptions and behavioral responses of the general public during the 2009 influenza A (H1N1) pandemic: A systematic review. Disaster medicine and public health preparedness. $2015 \mathrm{Apr} ;$ 9(2):207-19. 
12. Kwok KO, Li KK, Chan HH, Yi YY, Tang A, Wei WI, Wong YS. Community responses during the early phase of the COVID-19 epidemic in Hong Kong: Risk perception, information exposure and preventive measures. MedRxiv. 2020 Jan 1.

13. Ahmed F, Zviedrite N, Uzicanin A. Effectiveness of workplace social distancing measures in reducing influenza transmission: A systematic review. BMC public health. $2018 \mathrm{Dec} ; 18(1): 518$.
14. Goodwin R, Sun S. Public perceptions and reactions to H7N9 in Mainland China. Journal of Infection. 2013 Nov $1 ; 67(5): 458-62$.

15. Jang WM, Cho S, Jang DH, Kim UN, Jung H, Lee JY, Eun SJ. Preventive behavioral responses to the 2015 middle east respiratory syndrome coronavirus outbreak in Korea. International journal of environmental research and public health. 2019 Jan; 16(12):2161.

\begin{tabular}{|l|l|l|}
\hline \multicolumn{3}{|c}{ AUTHORSHIP AND CONTRIBUTION DECLARATION } \\
\hline Sr. \# & \multicolumn{1}{|c|}{ Author(s) Full Name } & \multicolumn{1}{c|}{ Contribution to the paper } \\
\hline 1 & Sohail Hassan & Concept, Design, Analysis. \\
\hline 2 & M. Adil Khurshid & Acquisition of data. \\
\hline 3 & Muhammad lqbal & Acquisition of data. \\
4 & Athar Hameed Sheikh & Acquisition of data. \\
\hline 5 & Ammad Ahmad Siddiqui & Acquisition of data. \\
6 & Manzoor Ahmad Naeem & Acquisition of data. \\
\hline
\end{tabular}

